可見光的诐长和它本身仍为非匀光体。如将这体系诺 行高度的均匀化（强力的研碳）之后，不但看不到个

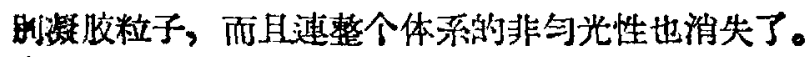

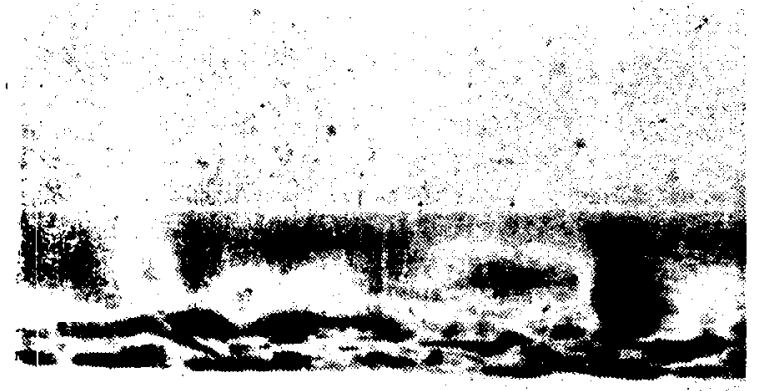

䟥 3

上面結果镜明了利用䶂光来研究潤沮脂或其他高 分子続构体系的宏观結构是有前途的。

本工作蒙張大显先生給予指导，謹致謝意。 陈紹澧 梁国霖 (中国科学院石油研究所) 195i年3月17日

[1] B. B. Farrington and W. N. Davis, Ind. and Eng. Chem. 28, 414 (1936).

[2] M. J. Vold, N. L. G. I. Spokesman, 16, No. 8 (1952).

[8] S. G. Ellis, Canadian J. of Res. 1947, (A) 119.

[4] B. B. Farrington and D. H. Birdsall, N. L. G. I. Spokesman, 11, No. 1 (1947).

[5] Г. В. Виноградов, Ж. П. Х. 28, No. 1,54(1955).

[6] 朱純綮，陈紹㨽，中国科学院石油研究所研究报告与 資数 No. 31 (1956)。

[7] B. W. Hotten, N. L. G. I. Spokesman, 19, No.1 (1955).

[8] Поляризационно-оптический мотоп исслодования налряжения (Сборник статөй), Изд. АНСССР, 1956.

\section{銓在液态 $\mathrm{Fe}-\mathrm{Mn}-\mathrm{C}$ 合金內的活度}

鉄錳䒺統由于 Körber 与 Oelsen[1,2] 及三本木 与火谷 ${ }^{[3]}$ 的研究, 可親为理想溶液, 即服从 Raoult 定律。作渚之一[4]曾研究錳在鉄液与銀液間的分配比 及碳对此項分配比的影响。因瑞在銀液中溶解度很 小，故分配比的变化可的見为碳对銔在鉄液內活度的影 响, 从而可求得 Fe-Mn-C㡜液》銛的活度。但是当 碳>4.2\%时必須应用外插, 从得到的数据看来（圆 1 得)，很难准确地外插到庭碳区域。

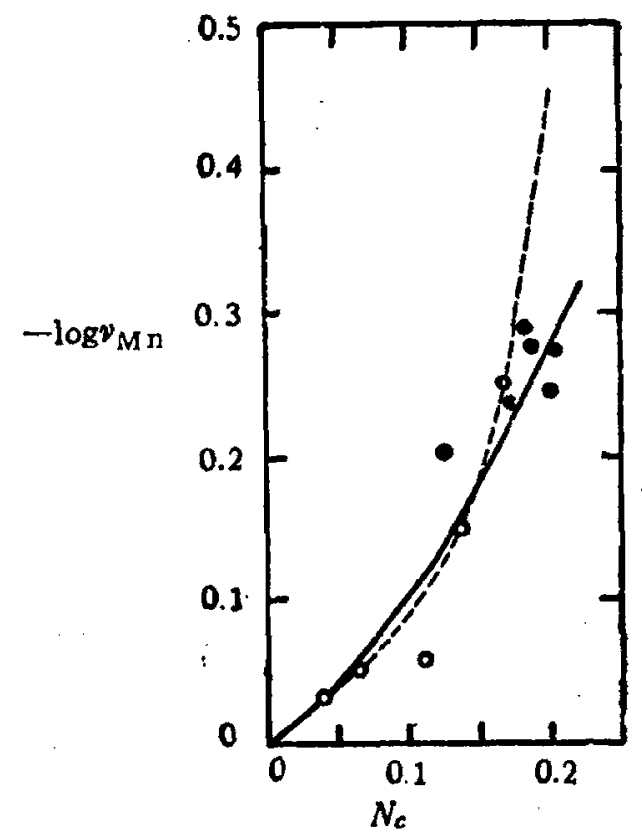

再 $1 \log \%$. Mn 与 $N_{c}$ 的关罙 $1450^{\circ}-1650^{\circ} \mathrm{C}$

本实验仍然利用文献 ${ }^{[4]}$ 的方法测定船在波态

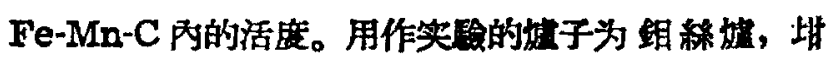
鍋材料用內徑 18 塞米，高 48 毫米的. Acheson 石显

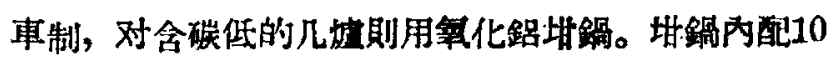
克电解銀、10克电解鉄以及要求含量的电解钴和石嘿 粉，放入嘘內熔化居待升至一定温度时用石墨㩲䢁棒 港䢁以加速达到分配平衡，約牛小时后即停止摼坢， 取出復䢁棒，在此温度下維持牛小时，使鉄、銀分展

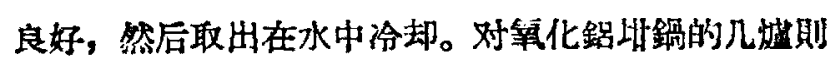

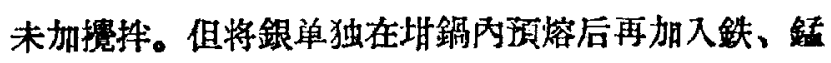
等試料，吏延长在墟內的时間至二小时。測温用光学 㬏温計，温度控制在士5 ${ }^{\circ} \mathrm{C}$ 以內。在实驗期間㠊內通 入 CO 用作保护气氛。

根据实驗所得的結果算出 $N_{c}$ 与 $\log \nu_{M n}$ 的关系， 以黑点示于圆 1, 圖中圆圈系交献 ${ }^{[4]}$ 的数据。可以看出

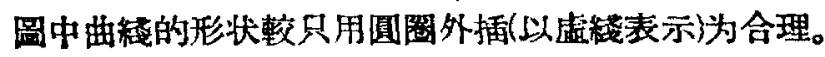

如文献 [4]所述, 温度变化 $1450^{\circ}-1650^{\circ} \mathrm{C}$ 对鉇 分配比無显著影响，故圖 1 中据点与曲綫閌的偏荎不 应硫是温度的影响，而可能是取样及分析誤差所致。

\section{王渭源 楖元烧}

\section{(中国科学院治金陶登明符所)}

1957 年 4 月 5 日

[1] F. Körber, W. Oelsen, Mitt. Kaiser-Wihelm Inst. Eisenforscil, 14, 181 (1932).

[2] F. Körber, Stahl u. Eisen, 52, 135 (1932),

[3] 三本顺治、大谷正康，铁卜鋮 (日本)，40 (3), $27 \%$ (1954).

[4] 元掝, D. Sc. Thes:s, Dept. of Metallurgy, Carnegie Inst. of Tecinology (1947). 